\title{
Skill and Knowledge Improvement Training on Honey and Propolis Commercialization in Central Bangka Regency
}

\author{
Gemilang Lara Utama ${ }^{1,2}$, Mahani ${ }^{1}$, Mohamad Djali ${ }^{1}$ \\ ${ }_{1}^{1}$ Faculty of Agricultural Industrial Technology, Universitas Padjadjaran \\ ${ }^{2}$ Center for Environment and Sustainability Science, Universitas Padjadjaran \\ E-mail: g.l.utama@unpad.ac.id; mahanijuli@gmail.com; djali@unpad.ac.id
}

Article History:

Received: 2021-03-24

Revised: 2021-04-20

Accepted: 2021-05-31

\begin{abstract}
The development of honey and propolis as commercial commodities from Central Bangka Regency meet an obstacle considering the technology and marketing target. In order to develop the potential of honey and propolis as commercial products from Central Bangka Regency, identification, technical training and monitoring has been done as the methodology. The results shows identification of Honey and Propolis productivities showed that estimated $19,785 \mathrm{~kg} /$ year honey, 3,957 $\mathrm{kg} /$ year propolis, with total Kelulut colonies of more than 3957 colonies will resulted. Meanwhile the quality aspect of Kelulut honey found diastase enzyme activity of $1.68 \mathrm{DN}$, with propolis quality shown polyphenol levels reaching $2587.95 \mathrm{mg} / \mathrm{kg}$ with the characteristics that preferred by consumers and industry. Training and monitoring could increase the skill and knowledge of farmer groups.
\end{abstract}

\section{Introduction}

Bee products are very diverse, ranging from honey, bee bread, pollen to beeswax ${ }^{1}$. But what is unique about the Trigona sp. or been known as Kelulut, the honey products have slightly sour flavor. Besides that, propolis which is bee glue which is used for selfprotection and to maintain a stable temperature in the hive were also potential. Propolis contains flavonoid compounds including natural phenolic compounds that are potential as antioxidants and have bioactivity as medicine ${ }^{2}$.

Various research proves that propolis is a powerful natural antibiotic. Propolis is a unique functional food. This material is called functional food because it is produced by

\footnotetext{
1 Anna Kurek-Górecka et al., "Bee Products in Dermatology and Skin Care,” Molecules 25, no. 3 (January 28, 2020), accessed March 20, https://www.ncbi.nlm.nih.gov/pmc/articles/PMC7036894/.

2 Joanna Kocot et al., "Antioxidant Potential of Propolis, Bee Pollen, and Royal Jelly: Possible Medical Application," Oxidative Medicine and Cellular Longevity 2018 (May 2, 2018), accessed March 25, 2021, https://www.ncbi.nlm.nih.gov/pmc/articles/PMC5954854/.
} 
bees and has a function to maintain a healthy body. Uniquely, apart from being a functional food, propolis is also proven as an ingredient for curing various infectious diseases ${ }^{3}$.

In the 2000s, propolis became known in the general market. The market response to this product is very good. Several conventional distribution companies have begun to look to get involved in marketing propolis. Some of them have started importing propolis extract to be processed in liquid form domestically. Currently, the domestic production of crude propolis is classified as sufficient, but it is still facing difficulties in processing it due to limited mastery of science and technology.

Currently, the public market is getting to know propolis well. In fact, this large market has not been followed by adequate production because the availability of propolis in nature is indeed limited 4 . This is a golden opportunity in providing liquid propolis supply by utilizing local propolis raw material which has not been tilled so far. One of them is propolis which comes from Central Bangka Regency.

Central Bangka Regency is one of the regencies in Indonesia that has an abundance of natural resources, namely tin. Along with the mining process that has been carried out since ancient times, the availability of tin is getting decrease ${ }^{5}$. This then makes the people of Central Bangka look to other sectors for their livelihood system, and one sector that has been revived is Kelulut Honey cultivation.

The government of Central Bangka Regency, Bangka Belitung Islands Province is currently developing a market for commodities from bees from far away from the region. One of the efforts that can be made to increase the impact of this program is through the development and commercialization of propolis products. Propolis is one of the potential commodities that can be developed in Central Bangka Regency considering the high production of another commodity from bees, namely honey. Inadequate expertise and facilities / infrastructure in producing propolis is the background that the product in question cannot be developed.

Various approaches and technology introductions can be made in increasing the aspects of knowledge and expertise in the development of production and commercialization of the propolis commodity from Central Bangka Regency. Increased knowledge and skills of beekeepers in producing raw propolis based on Good Handling

\footnotetext{
${ }^{3}$ Vijay D. Wagh, "Propolis: A Wonder Bees Product and Its Pharmacological Potentials," Advances in Pharmacological Sciences $2013 \quad$ (2013), accessed March 25, 2021, https://www.ncbi.nlm.nih.gov/pmc/articles/PMC3872021/.

${ }^{4}$ Aghita Ade Novia Hirmarizqi et al., "Identifikasi Lebah Kelulut Asal Bangka dan Pendataan Jenis Tumbuhan Penghasil Resin Bahan Baku Pembuatan Propolis” (2019): 6.

${ }^{5}$ Luna Febriani and Putra Pratama Saputra, "Modal Sosial Dalam Pengembangan Madu Kelulut Sebagai Komoditas Ekonomi Dan Pariwisata Di Kecamatan Lubuk Kabupaten Bangka Tengah," Society 6, no. 2 (December 31, 2018): 83-91.
} 
Practices (GHP) will be able to guarantee the production of the highest quality propolis raw material. Procurement of production facilities / infrastructure with transfer of knowledge related to the best extraction method in propolis production will help produce propolis products that are acceptable to the market. Meanwhile, assistance in the aspects of packaging and quality assurance is expected to continue to maintain the quality of the products produced so that marketing assurance can be maintained.

\section{Method}

The activities carried out in Central Bangka Regency, Bangka Belitung Island Province, Indonesia involving Forest Farmer Groups in Central Bangka Regency who already raised Kelulut. Community empowerment through training and monitoring was applied to improve skill and knowledge in processing Kelulut product and its derivative. There are three stages conducted such as preliminary stage, consultation and technical training stage with the last stage is monitoring and quality assurance stage (Figure 1).
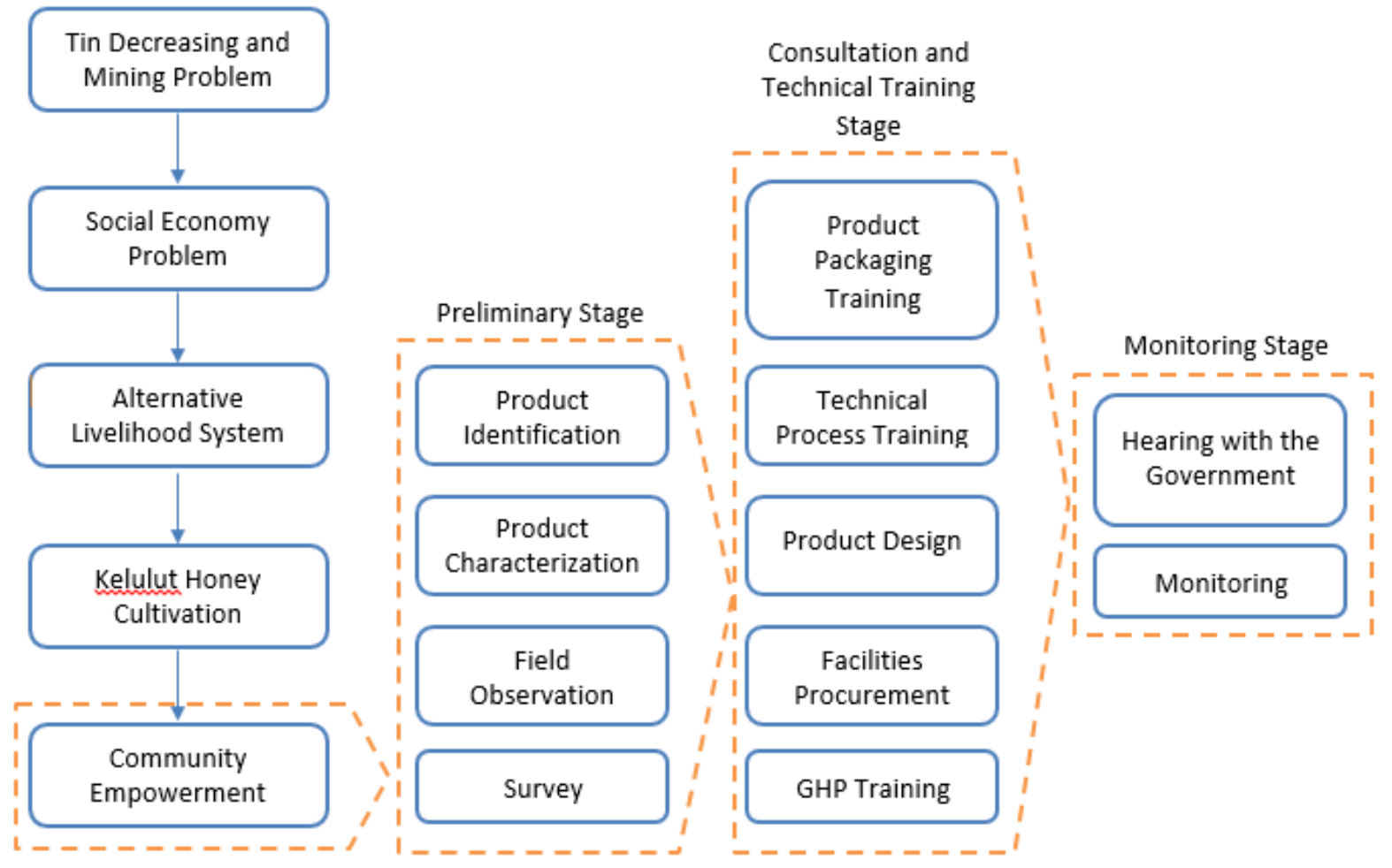

Figure 1. Community empowerment in Kelulut Commercialization

Preliminary stage: (1) Conducting surveys and field observations to areas that have the potential to produce propolis, (2) Identifying the characteristics of the crude propolis produced. Consultation and Technical Training stage: (1) GHP training, (2) 
Facilitites procurement, (3) Product design, (4) Technical training, (5) Packaging training. The last stage is monitoring stage of the continuity of Propolis production. The whole stages aimed to achieve the outcomes in table 1.

Table 1. Activity Outcome Indicators

\begin{tabular}{lll}
\hline No. & \multicolumn{1}{c}{ Indicator } & \multicolumn{1}{c}{ Achievements } \\
\hline 1 & $\begin{array}{l}\text { Knowledge and skills in } \\
\text { producing GHP-based raw } \\
\text { propolis. }\end{array}$ & $\begin{array}{l}\text { Participants are able and skilled to produce } \\
\text { raw propolis by paying attention to the aspects } \\
\text { of GHP. }\end{array}$ \\
2 & $\begin{array}{l}\text { Knowledge of the characteristics } \\
\text { and qualities of Propolis } \\
\text { Pnowledge and skills in } \\
\text { producing Propolis by } \\
\text { puality of the raw Propolis produced } \\
\text { operationalizing the available } \\
\text { facilities. }\end{array}$ & $\begin{array}{l}\text { Participants are able and skilled to produce } \\
\text { propolis by operating the available facilities } \\
\text { effectively and efficiently. }\end{array}$ \\
\hline
\end{tabular}

\section{Result}

\section{Preliminary Survey}

Preliminary survey and field observation activities were carried out in Koba, Central Bangka (Figure 2). Activities include field surveys, initial meetings with agencies and forest farmer groups who raise bees and early identification of potentials and weaknesses of maintenance activities and commodities developed by farmer groups.

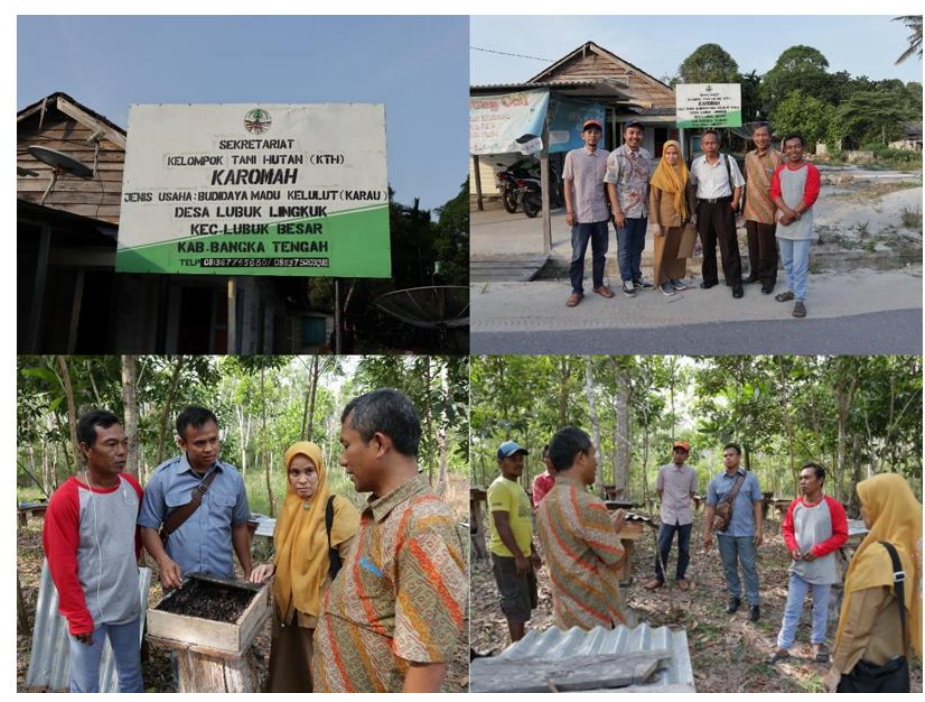

Figure 2. Documentation of Preliminary Survey and Field Observation

The results of the survey and preliminary observations obtained the following information: (a) Farmer Groups have now succeeded in developing Kelulut honey and other derivative products but still need strengthening in terms of quality and marketing; 
(b) The maintenance model owned by forest farmer groups in the Koba region and its surroundings shows several weaknesses, including the lack of understanding of the types and variations of forage plants that need to be planted around the colony in the hope that it can affect the characteristics of the honey and its derivative products so that they are easily commercialized; (c) The development of ecotourism based on commodity bee products and its derivatives has been carried out only due to disturbance of pests (apes) so that existing colonies tend to decrease due to being consumed by animals around the ecotourism area; (d) Need a clear cooperation scheme between farmers and industry bridged by related agencies and academics, in this case Universitas Padjadjaran.

\section{Characterization of Honey and Propolis from Central Bangka Regency}

As a follow-up to the preliminary survey and field observations, the team identified the potential for developing honey and propolis as superior commodities for Central Bangka Regency. The results of initial identification, there are 4 forest farmer groups that actively cultivate Kelulut and utilize the honey as a commodity that is traded. The four groups are the Karomah, Seribu Bunga, Karau and Darurrohmah groups.

Table 1. Estimated Productivity of Honey and Propolis in Central Bangka Regency

\begin{tabular}{cccc}
\hline Group name & $\begin{array}{c}\text { Colony } \\
\text { number }\end{array}$ & \multicolumn{2}{c}{ Estimated Productivity per Year } \\
\cline { 3 - 4 } & 987 & Honey (Kg) & Propolis (Kg) \\
\hline Karomah & 300 & 4935 & 987 \\
Seribu Bunga & 2100 & 1500 & 300 \\
Karau & 570 & 10500 & 2100 \\
Darurrohmah & $\mathbf{3 9 5 7}$ & 2850 & 570 \\
\hline Total & $\mathbf{1 9 , 7 8 5}$ & $\mathbf{3 , 9 5 7}$ \\
\hline
\end{tabular}

Table 1 shows that of the four groups it can be estimated that the productivity of bee products produced by Central Bangka Regency through the sale of honey and propolis commodities. With total colonies reaching 3,957 colonies, in the best conditions it can be estimated that the potential for Kelulut honey production can reach 19,785 kg / year and propolis up to $3,957 \mathrm{~kg} /$ year. This is very prospective because the availability of natural food for Kelulut in Central Bangka Regency is very abundant, and it is possible to exceed this estimate considering that the productivity of Kelulut owned by forest farmer groups in Central Bangka Regency is very high, recorded almost 1.5-2 times the usual productivity of Kelulut.

The potential of honey and propolis as superior commodities in Central Bangka Regency is not only supported by their productivity but also the quality of their products. As presented in Table 2, the results of laboratory analysis of the honey of trigona Kab. Central Bangka has fulfilled SNI 8664: 2018 for Honey. Parameters 1-5 indicate no 
detection of hazardous chemicals, either in the form of food additives that are intentionally added as preservatives or heavy metals, which means that honey products are safe for consumption. The amount of reducing sugar will be related to the characteristic taste of honey, which is sweet and sour, which is a characteristic that is sought in Kelulut honey. Another parameter is the undetectable saccharose, which means that it ensures the authenticity of the sweetness of the honey and indicates that there is no added sugar in the resulting honey product. Another parameter that is not less important is the diastase enzyme activity which exceeds the SNI (1.5 DN), namely reaching $1.68 \mathrm{DN}$ which also determines the efficacy of honey products. This result also mentioned by Evahelda ${ }^{6}$ that found 1.64 DN diastase enzyme activities from Bangka Kelulut Honey.

Table 2. The Quality of Kelulut Honey and Propolis of Central Bangka Regency

\begin{tabular}{|c|c|c|c|c|}
\hline No & Parameter & Unit & Result & Limit $^{7}$ \\
\hline 1 & Chloramphenicol & $\mu \mathrm{g} / \mathrm{kg}$ & ND & $\leq 0.1$ \\
\hline 2 & As & $\mathrm{mg} / \mathrm{kg}$ & ND & $\leq 0.00015$ \\
\hline 3 & $\mathrm{Hg}$ & $\mathrm{mg} / \mathrm{kg}$ & ND & $\leq 0.003$ \\
\hline 4 & $\mathrm{Cd}$ & $\mathrm{mg} / \mathrm{kg}$ & ND & $\leq 0.00012$ \\
\hline 5 & $\mathrm{~Pb}$ & $\mathrm{mg} / \mathrm{kg}$ & ND & $\leq 0.00001$ \\
\hline 6 & Reducing sugar & $\%$ & 63.43 & \\
\hline 7 & Saccharose & $\%$ & ND & $\leq 0.28$ \\
\hline 8 & Taste & & Sweet sour & \\
\hline 9 & Odor & & Normal & \\
\hline 10 & Moisture & $\%$ & 22.64 & \\
\hline 11 & Acidity & $\mathrm{mL} \mathrm{NaOH} 1 \mathrm{~N} / \mathrm{Kg}$ & 53.38 & \\
\hline 12 & Total insoluble solid & $\%$ & 0.10 & \\
\hline 13 & Ash & $\%$ & 0.23 & \\
\hline 14 & Diastase Enzyme & DN & 1.68 & \\
\hline 15 & Hydroxyl methyl Furfural & $\mathrm{mg} / \mathrm{kg}$ & ND & $\leq 0.015$ \\
\hline 16 & Polyphenol of Propolis & $\mathrm{mg} / \mathrm{kg}$ & $2,587.95$ & 1,000 \\
\hline
\end{tabular}

*ND= not detected

Apart from honey, the potential for propolis is also very promising considering the results of the analysis of propolis quality are shown. The results of the analysis show that the polyphenol content of propolis is almost 3 times higher than the polyphenol content of the National Standard for liquid propolis which ranges from $1000 \mathrm{mg} / \mathrm{kg}$. Polyphenol

${ }^{6}$ Evahelda et al., "Chemical Characteristics of Kelulut Honey (Trigona Sp.) in Bangka Tengah District, Indonesia," IOP Conference Series: Earth and Environmental Science 694, no. 1 (March 1, 2021): 012072.

${ }^{7}$ BSN National Standard Agency, "Standar Nasional Indonesia (SNI) Nomor 01-3545-2004 Tahun 2004 Tentang Madu” (National Standard Agency, 2004). 
levels reaching 2,587.95 mg/kg indicate biological activity and have the potential to have good efficacy.

\section{Knowledge on Cultivation and Postharvest Handling of Kelulut Products}

The implementation of training on the cultivation and post-harvest handling of trigona bee products was carried out for 2 days, namely on 14-15 October 2019. On the first day of training, some knowledge material was given as follows: (1) Stingless Bee Cultivation for the production of Honey, Propolis and Bee Pollen; (2) Propolis harvesting and refining methods; (3) Food safety for honey products and their derivatives; (4) Packaging of honey products and their derivatives; (5) E-commerce and Marketplace, online marketing potential.

Meanwhile, for the second day, practical training on making propolis blocks was conducted using 2 types of methods, namely cold and hot methods. The training was attended by representatives from 4 forest farmer groups as well as extension workers with a composition as shown in Figure 3. The participation of the honey farmer was shown by the success in the propolis making training. The successful participation shows by the ability of the honey farmers in making propolis with two different methodologies as the results shown in Figure 6.

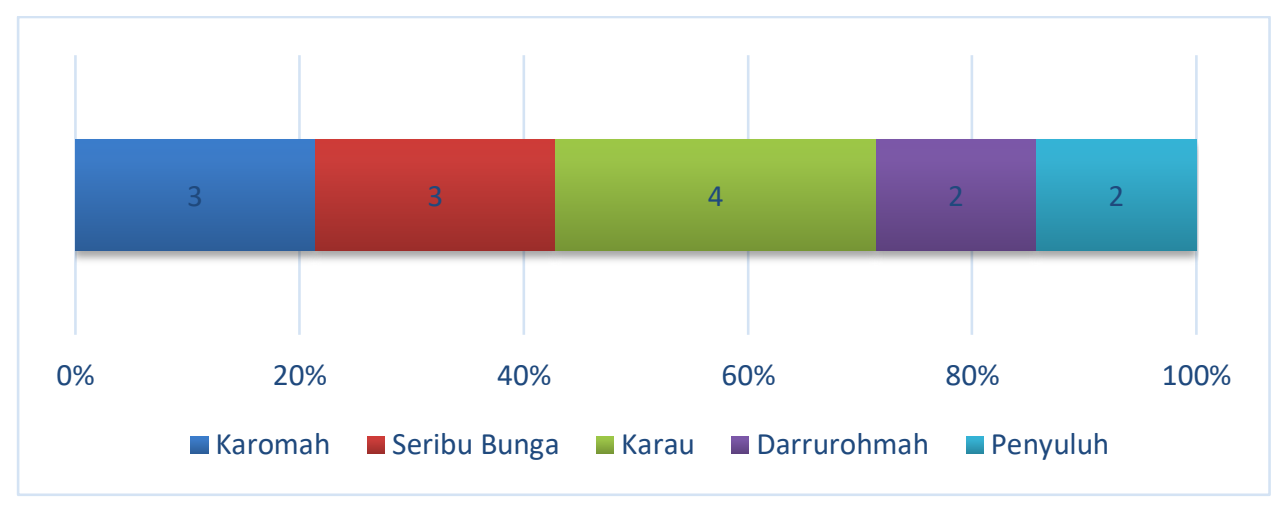

Figure 3. Participants Composition

The results of the training showed that the participants had a good understanding with an average of knowledge about Kelulut cultivation and post-harvest products reaching a score of $73.81 \%$. Meanwhile, the potential for marketing development is also very possible to do considering the score related to marketing reaches an average of $80 \%$ (very good). This result is very prospective considering that $100 \%$ of participants have never previously received similar training. However, in order to maximize the empowerment carried out, it is necessary to pay attention to enrichment and assistance related to cultivation and post-harvest knowledge which is more intensive in 2 groups, namely Karomah and Seribu Bunga, considering the results shown in Figure 4. Both 
groups still show low knowledge so that they are vulnerable to business sustainability is very high. For this reason, assistance by extension agents is very necessary, given the strength of good extension agents with an average knowledge ability of $83.33 \%$ (very good). Meanwhile, 2 other groups (Karau and Darrurohmah) showed very good knowledge, reaching $81.25 \%$ and $87.50 \%$.

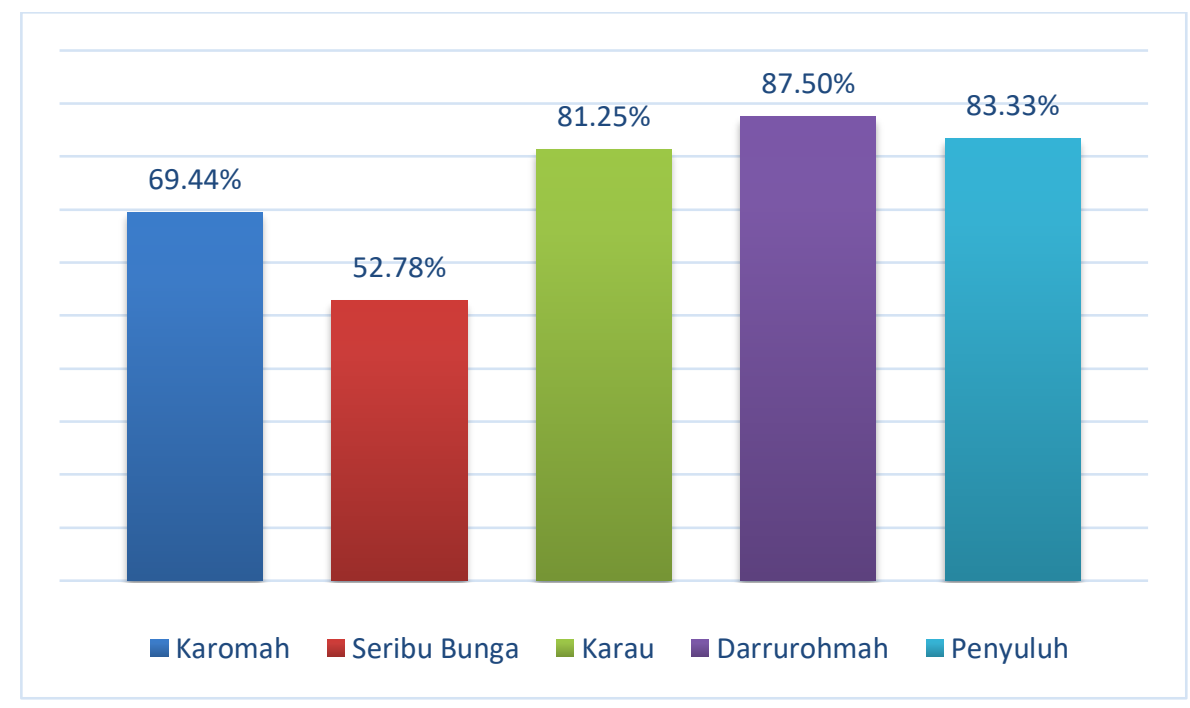

Figure 4. Knowledge of Kelulut Cultivation and Postharvest of Kelulut Product

The same result applies to the potential for marketing development. It can be seen in Figure 5 that 2 groups, namely Karamah and Seribu Bunga, need assistance in developing marketing through online media. Currently, there are many SMEs which are greatly helped by online marketing. Therefore, the role of extension personnel can also be maximized considering their excellent ability (90\%) in this regard. Meanwhile, for the other 2 groups, namely Karau and Darrurohmah, some of the members have been doing online marketing so that they have the potential to further developed. 


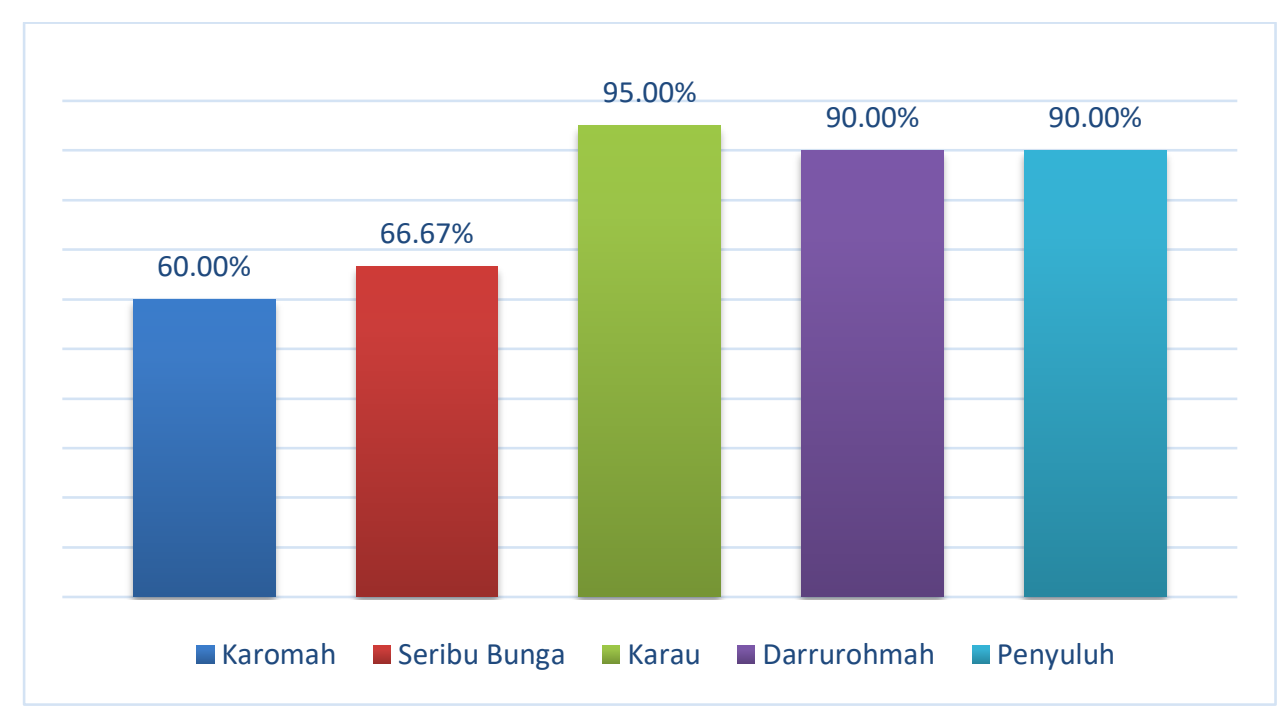

Figure 5. The Potential of Online Based Marketing Development

The training also identified some of the obstacles faced by the group. The main thing is marketing, almost all groups find it difficult to market their products even though they have used online media. The next obstacle is the ability to breed the colonies owned so that the colonies currently owned are still very limited in number and so far tend to buy colonies from other farmers who get them from the forest. Furthermore, the problem of pests (apes) and feed enrichment to produce diversified products with the quality desired by industry and consumers.

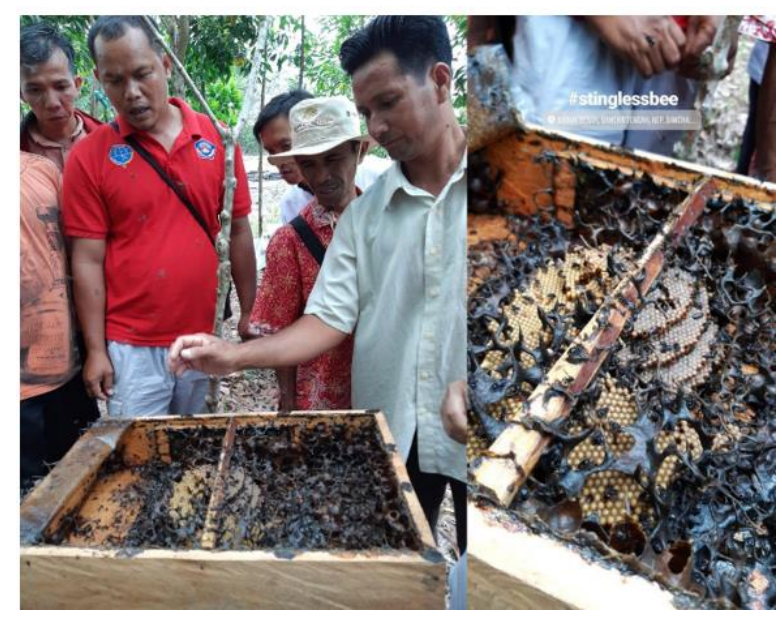

Figure 6. Kelulut colony eggs reach the topping

From these obstacles, several solutions are offered. For marketing constraints, a collaborative solution with PT. Nutrima who can receive products produced by groups with a designated person in charge. The collaboration was followed up with a discussion with the instructor who took the role of the person in charge with PT. Nutrima so that it can also be a solution to the uncertainty of price. The next solution is the Kelulut breeding 
where the potential is very prospective to be developed considering that the Kelulut colony owned has differences with other regions. The fundamental difference is that there are eggs and toppings (Figure 6), which can be one of the factors that can increase the success of Kelulut breeding. Another solution is the application of controlled colony cages to reduce the risk of pests (apes) as well as planting a variety of forage plants according to the desired commodity, whether the plants are nectar, resin or pollen based.

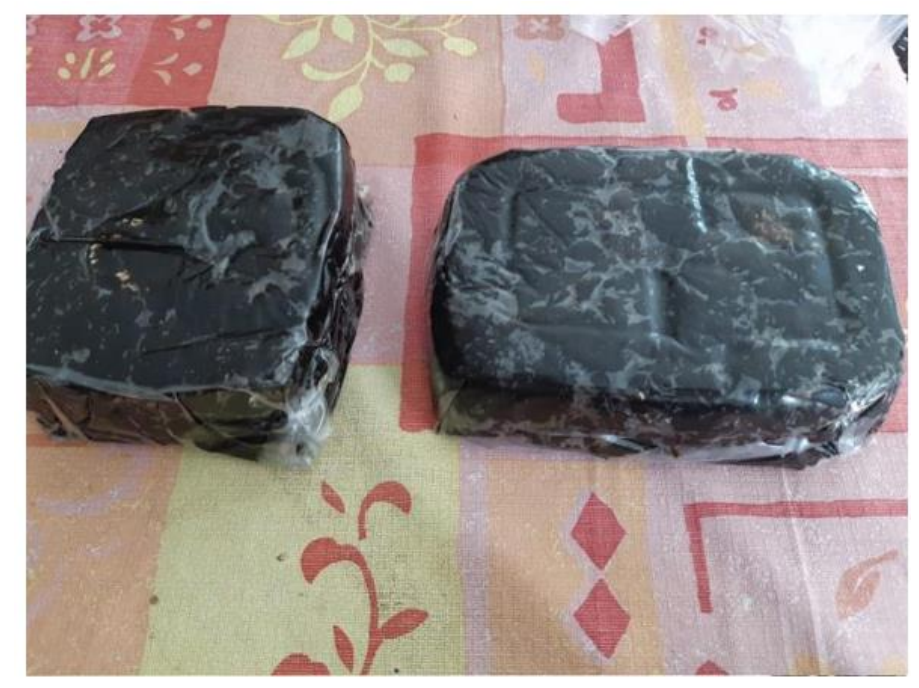

Figure 7. Propolis with the cold method (left), the hot method (right)

The results of the training in making propolis blocks are also promising, given the results obtained by the participants. The resulting propolis beam has shown conformity to the standards desired by the industry and is prospective if a marketing collaboration is carried out. Figure 7 shows the results of the Propolis blocks made by the training participants (Fiagure 8). 


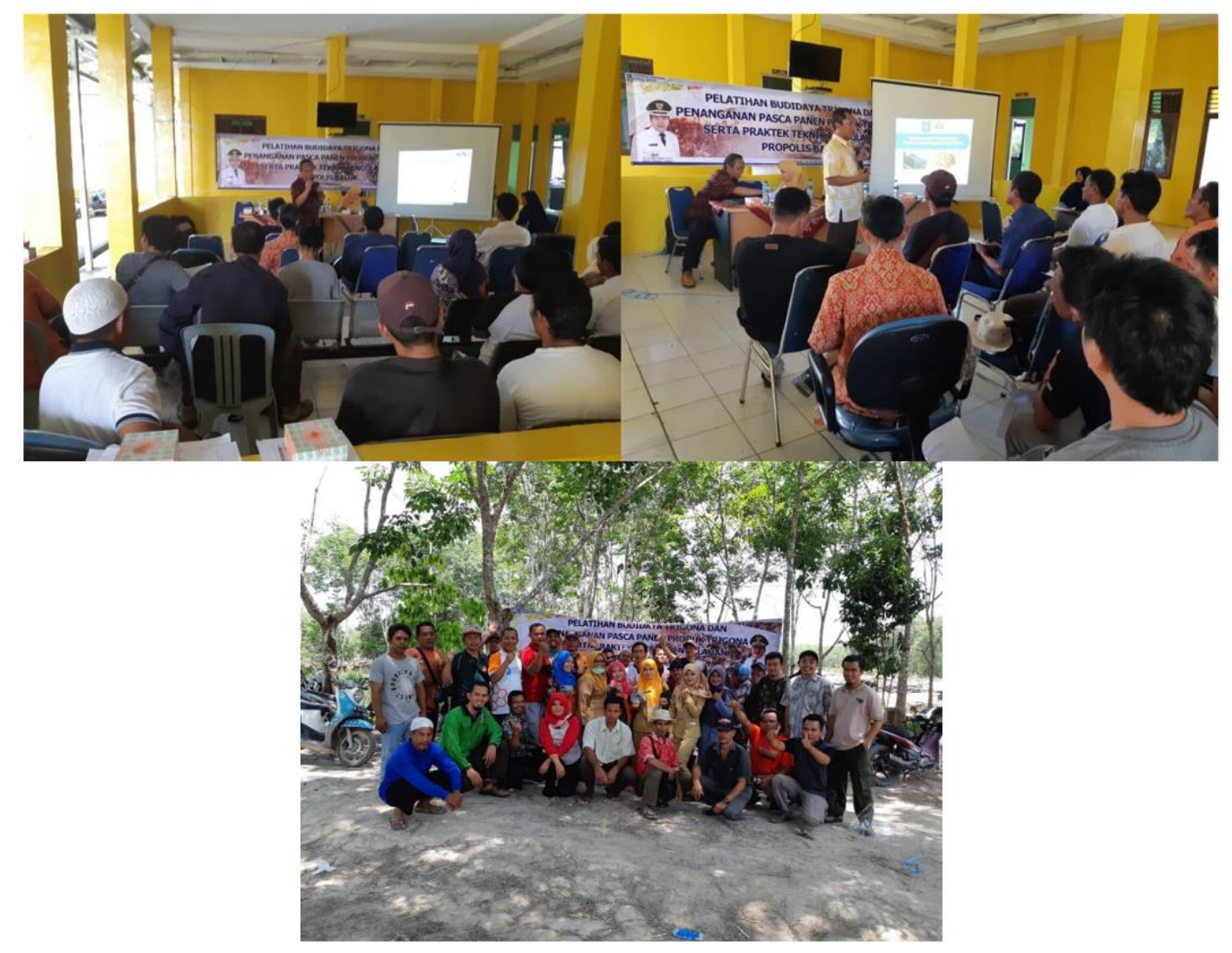

Figure 8. Documentation of training activities

\section{Hearings and Monitoring}

The results of the activity to identify the potential for the development of superior commodities that have been carried out are conveyed through an audience to the Regional Government of Central Bangka Regency (Figure 9). The hearing was held on November 20, 2019 which was attended by various related SKPDs and produced several things that could be followed up, including: (1) Assistance for Productivity of Honey, Propolis and Pollen from Kelulut; (2) Marketing cooperation with industry (PT. Nutrima; (3) Development of the Kelulut Breeding Center in Central Bangka Regency; (4) Reconstruction of Bees Mangrove Eco-tourism in Central Bangka Regency

As a follow-up and consideration in determining future program development, on November 21, 2019, a survey was conducted on the mangrove areas that had been used as ecotourism locations (Figure 9). The results obtained include: (1) Improvements need to be made, especially in the construction of the barracks for the Kelulut colony protection frame; (2) The mangrove area has the potential to be repaired and developed not only as ecotourism but also as a breeding center considering the abundance of forage plants; (3) Ecotourism schemes with the involvement of local community-based food SMEs can be developed in the Mangrove area in order to increase income and community 
participation.

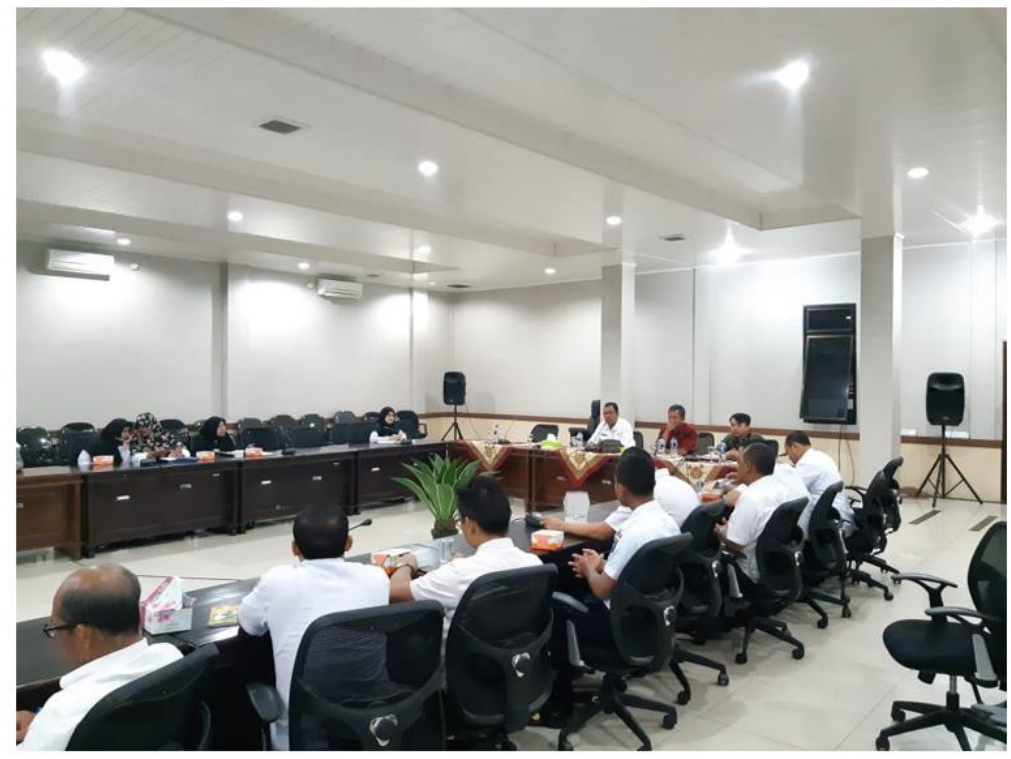

Figure 9. Documentation of hearing activities

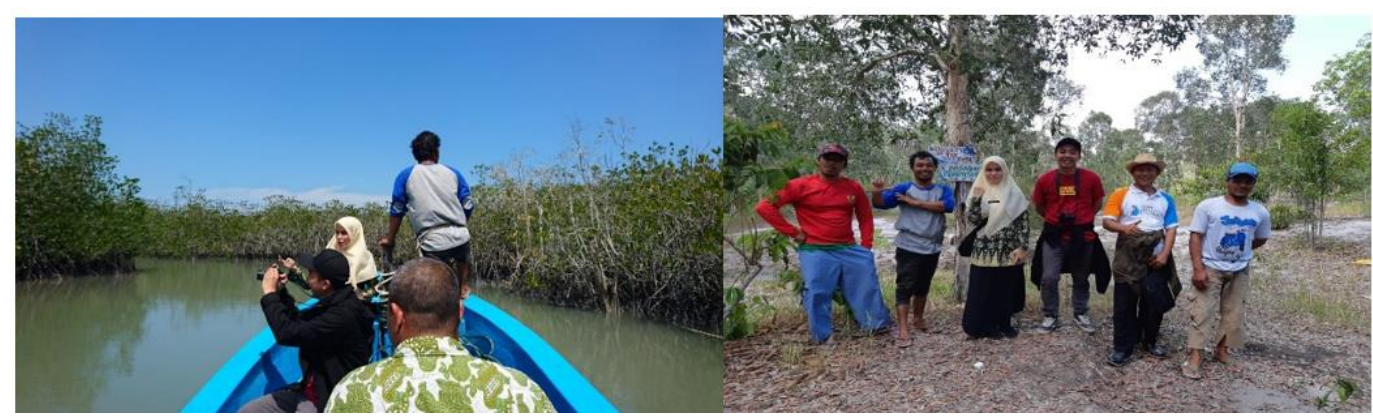

Figure 9. Mangrove area observation documentation

\section{Discussion}

The driving factor for the cultivation of Kelulut honey in Central Bangka Regency begins with the needs to find alternative livelihood system. Many people in Central Bangka work as unconventional tin miners, meanwhile tin supplies have recently been running low and the existence of the unconventional tin becoming prohibited. This is what triggers the innovation of the Central Bangka Regency community to create the cultivation of Kelulut honey as support system of their economy 8 .

Improving the Kelulut honey exsistence as community new livelihood system requires competent and high integrity facilitators including the roles of the government. The facilitators can consist of government officials, NGO activists and community leaders themselves. In the case of the empowerment of the Central Bangka Regency, the role of

${ }^{8}$ Febriani and Saputra, "Modal Sosial Dalam Pengembangan Madu Kelulut Sebagai Komoditas Ekonomi Dan Pariwisata Di Kecamatan Lubuk Kabupaten Bangka Tengah." 
the government as a companion cannot be separated, this can be seen where when the community began to promote the cultivation of Kelulut honey, the government through its Forestry Service provided information and insight about this in the form of seminars that brought competent sources ${ }^{9}$. As mentioned in Nurgroho ${ }^{10}$, the government can drive the community empowerment process through appropriate program because already recognize the community characteristics.

Empowerment as a process of change requires ideas, products, ideas, methods, tools and technology. As shown through the empowerment methodology how the tools provided and the skill and knowledge were improved through the training for the Central Bangka Recgency Community especially the Forest Farmer Groups that cultivated Kelulut. It is comply with the empowerment mentioned by Sianipar 11 that said how outsiders give knowledge or tools to local people, teach them how to use and maintain those knowledge and tools using better methods, and also teach them how to make by themselves, adjusting the function based on required conditions.

\section{Conclusion}

Honey and propolis have the potential to be developed as superior commodities in Central Bangka Regency, especially by considering the quantity and quality of the products produced. Four forest farmer groups that are currently active show the potential for Kelulut honey production is estimated to reach 19,785 kg / year and propolis reaching 3,957 kg / year, with total colonies currently reaching 3957 colonies. In terms of quality, it can be proven that it exceeds the National Standard with diastase enzyme activity, namely $1.68 \mathrm{DN}$, polyphenol levels reaching $2587.95 \mathrm{mg} / \mathrm{kg}$ with characteristics of sweet and sour taste that are preferred by consumers and can be accepted by the industry. This result was also strengthened by the ability of forest farmer groups to process block propolis during the training, although the distribution of knowledge still needed to be done, especially for 2 farmer groups, namely Karomah and Seribu Bunga. Long-term development can be carried out by collaborating with the Industry, which is currently being explored with PT. Nutrima, and guaranteed productivity can be supported by developing a trigona breeding center. The sustainability of honey and propolis productivity can also be strengthened by reconstructing the former

${ }^{9}$ Ibid.

10 Hanantyo Sri Nugroho and Desiana Rizka Fimmastuti, "Elite and Empowerment of Local Communities: The Dilemma Between Participation and Mobilization in The Era of Democracy," Journal of Governance 5, no. 2 (December 22, 2020), accessed June 20, 2021, https://jurnal.untirta.ac.id/index.php/jog/article/view/8971.

11 Corinthias Pamatang Morgana Sianipar et al., "Community Empowerment through Appropriate Technology: Sustaining the Sustainable Development," Procedia Environmental Sciences 17 (2013): 10071016. 
mangrove ecotourism area by improving the construction of protective frames, developing colony barracks and developing ecotourism schemes with comprehensive assistance from all related parties.

\section{Acknowledgements}

Authors thank to the government of Central Bangka Regency, Bangka Belitung Islands Province, Indonesia.

\section{References}

Evahelda, I Setiawan, S N Aini, and Z L Afriani. “Chemical Characteristics of Kelulut Honey (Trigona Sp.) in Bangka Tengah District, Indonesia." IOP Conference Series: Earth and Environmental Science 694, no. 1 (March 1, 2021): 012072.

Febriani, Luna, and Putra Pratama Saputra. “Modal Sosial Dalam Pengembangan Madu Kelulut Sebagai Komoditas Ekonomi Dan Pariwisata Di Kecamatan Lubuk Kabupaten Bangka Tengah." Society 6, no. 2 (December 31, 2018): 83-91.

Hirmarizqi, Aghita Ade Novia, Eka Sari, Rosha Kurnia Fembriyanto, Nur Annis Hidayati, and Rossy Hertati. "Identifikasi Lebah Kelulut Asal Bangka dan Pendataan Jenis Tumbuhan Penghasil Resin Bahan Baku Pembuatan Propolis” (2019): 6.

Kocot, Joanna, Małgorzata Kiełczykowska, Dorota Luchowska-Kocot, Jacek Kurzepa, and Irena Musik. "Antioxidant Potential of Propolis, Bee Pollen, and Royal Jelly: Possible Medical Application." Oxidative Medicine and Cellular Longevity 2018 (May 2, 2018). Accessed March 25, 2021. https://www.ncbi.nlm.nih.gov/pmc/articles/PMC5954854/.

Kurek-Górecka, Anna, Michał Górecki, Anna Rzepecka-Stojko, Radosław Balwierz, and Jerzy Stojko. "Bee Products in Dermatology and Skin Care." Molecules 25, no. 3 (January 28, 2020). Accessed March 25, 2021. https://www.ncbi.nlm.nih.gov/pmc/articles/PMC7036894/.

National Standard Agency, BSN. "Standar Nasional Indonesia (SNI) Nomor 01-3545-2004 Tahun 2004 Tentang Madu." National Standard Agency, 2004.

Sianipar, Corinthias Pamatang Morgana, Gatot Yudoko, Akbar Adhiutama, and Kiyoshi Dowaki. “Community Empowerment through Appropriate Technology: Sustaining the Sustainable Development." Procedia Environmental Sciences 17 (2013): 10071016.

Sri Nugroho, Hanantyo, and Desiana Rizka Fimmastuti. "Elite and Empowerment of Local Communities: The Dilemma Between Participation and Mobilization in The Era of Democracy." Journal of Governance 5, no. 2 (December 22, 2020). Accessed June 
20, 2021. https://jurnal.untirta.ac.id/index.php/jog/article/view/8971.

Wagh, Vijay D. "Propolis: A Wonder Bees Product and Its Pharmacological Potentials." Advances in Pharmacological Sciences 2013 (2013). Accessed March 25, 2021. https://www.ncbi.nlm.nih.gov/pmc/articles/PMC3872021/. 